\title{
SEASONAL AND SPATIAL VARIATION OF TRACE ELEMENTS IN SEDIMENTS OF THREE CHILEAN BASINS
}

\author{
SYLVIA V. COPAJA* AND ROXANA M. TESSADA \\ Depto. de Química, Facultad de Ciencias. Universidad de Chile. Las Palmeras 3425, Ñuñoa. Santiago. Chile.
}

\begin{abstract}
Total concentrations of trace elements can provide fundamental information on the sediment contamination levels of the pollution indexes and the quality guidelines for sediment risk assessment. However, this information alone is insufficient to understand the mobility, bioavailability and toxicity of these elements in the sediment, since the environmental behavior of trace elements depends largely on their chemical form and binding states. Thus it is important to determine the soluble or labile fraction, since the elements of this fraction will be the most mobile and bioavailable.

In this study we analyze the seasonal and spatial variation of labile fraction trace elements concentration in three Chilean river basins. We also study the impact of mining nearby in one of the sites studied in the three basins.

Samples were taken in spring (November); summer (January), autumn (May) and winter (June). Sediment samples from three selected basins: Aconcagua, Cachapoal and Choapa basins were collected at different points in the river. Six sampling points were chosen in three areas: one station without human intervention (ritron: E1), two in the area of middle ritron (E2-E3) and a third in the sector potamon where increased sedimentation (E4-E5-E6). In the three basins site E2 could be influenced by mining activities, site E2 in the Cachapoal basin is influenced by the El Teniente mine; site E2 in the Aconcagua basin influenced by the Cerro Blanco mine and site E2 in the Choapa basin is influenced by the Los Pelambres mine.

Physical chemical characteristic of sediment were done by described methods. The labile or soluble fraction of $\mathrm{Al}, \mathrm{As}, \mathrm{Cd}, \mathrm{Cu}, \mathrm{Cr}, \mathrm{Fe}, \mathrm{Mn}, \mathrm{Mo}, \mathrm{Ni}, \mathrm{Pb}$ and $\mathrm{Zn}, \mathrm{was}$ extracted from the sediment with acetic acid. Metals were analyzed by ICP-OES.

The eleven trace elements analyzed in the labile fraction were detected in the three basins in most of the stations. The high concentration of $\mathrm{Al}, \mathrm{Cu}, \mathrm{Fe}, \mathrm{Mn}, \mathrm{Zn}$ in the labile fraction found in the E2 site in the three basins demonstrates the influence of mining activities near this site. The mobility of trace elements to the other sites is depending on the characteristics of the basins. Variation between seasons and sites was observed.
\end{abstract}

Keywords: Sediments, trace elements, labile fraction, seasonal variation, cluster analysis.

\section{INTRODUCTION}

Trace elements contamination of aquatic bodies is one of the environmental problems that accompany rapid economic development in both developed and developing countries ${ }^{1}$. The concentration of trace elements in natural ecosystems is generally low, but deposition from anthropogenic sources can increase the concentration considerably ${ }^{2}$. The mining industry has been recognized as the primary anthropogenic source of trace elements in the environment. Other sources of trace elements include industrial and domestic waste discharges, traffic-related emissions such as vehicle exhaust, gasoline and oil leakage ${ }^{3}$. In the aquatic environment trace elements are adsorbed on the sediment, which serves as an ecological sink ${ }^{4}$. There is always a treat of transference of these metals from the sediment phase to the overlaying water column as a function $\mathrm{pH}$, temperature, salinity, etc.; in the aquatic environment these metals rapidly become integrated into the food web and effect the aquatic biota, as well as people relying on them ${ }^{5}$.

One of the most serious environmental issues concerning trace elements, which distinguish them from other toxic pollutants, is that they are resistant to biodegradation and have the potential to bio-accumulate and become biomagnified, increasing the exposure of aquatic communities and human populations through the trophic chain ${ }^{1,6}$.

As the principal compartment of trace elements accumulation, the assessment of sediment quality plays an important role in the good ecological and chemical status of water ${ }^{7}$. The sediment matrix constitutes one of the most important sources of water contamination by trace elements, as well as an important carrier of these hazardous substances within the rivers, reservoirs and other waters ${ }^{8,9}$. Consequently, the preservation of this compartment is an important step to maintain the full quality of water bodies.

The fractionation of metals in sediment is therefore a critical factor in assessing their potential environmental impacts ${ }^{10}$; it can be determined with the use of sequential extraction procedures ${ }^{11,12}$. Total concentrations of trace elements can provide fundamental information on the sediment contamination levels of the pollution indexes and the quality guidelines for sediment risk assessment. However, this information alone is insufficient to understand the mobility, bioavailability and toxicity of these elements in the sediment, since the environmental behavior of trace elements depends largely on their chemical form and binding states. Thus it is important to determine the soluble or labile fraction, since the metals of this fraction will be the most mobile and bioavailable.

Water pollution from mining activities is a concern for many rivers around the world ${ }^{13,14}$. Mining discharges into rivers in Chile can have detrimental effects on the natural aquatic ecosystem, but natural orogenic processes, volcanic activity, geology and arid climatic regime can also explain the high trace elements concentrations in Chilean freshwater systems ${ }^{15-17}$. Although it is difficult to separate natural from anthropogenic effects on trace elements concentration, determining whether trace elements concentrations have increased over time may give us insights into the effect of mining pollution. Current studies of Chilean rivers have revealed an increase in the concentration of trace elements during the last two decades ${ }^{15}$; detected a positive temporal trend in arsenic concentration in the Elqui River, which may be associated with the beginning of activities of a large gold mine the 1980s. Other studies have suggested that mining discharges into important Chilean rivers (e.g. Limari, Choapa and Maipo), can be important to account for high concentrations of $\mathrm{Cu}$, $\mathrm{Zn}, \mathrm{Cd}, \mathrm{Fe}, \mathrm{Mn}$, and $\mathrm{Pb}{ }^{15}, 16,18$.

The aim of this study was to determine: i) The trace elements concentrations in soluble fraction in sediments of the three Chilean basins. ii) The mobility of trace elements along the river. iii) Seasonal variation and iv) the impact in $\mathrm{Cu}$ and others trace elements concentration in the selected sites due to mining activities.

\section{EXPERIMENTAL}

\subsection{Area description}

The Aconcagua River $\left(32^{\circ} 54^{\prime} 54^{\prime \prime} \mathrm{S} 71^{\circ} 30^{\prime} 30^{\prime \prime} \mathrm{W}\right)$ arises from the conflux of two minor tributary rivers at 1,430 meters $(4,690 \mathrm{ft})$ above sea level in the Andes, the Juncal River from the east (which arises in the Nevado Juncal) and the Blanco River from the southeast. The Aconcagua River flows westward through the broad Aconcagua Valley and enters the Pacific Ocean near the city of Concón, 20 kilometers (12 mi) north of Valparaíso ${ }^{19}$. 
The Cachapoal River $\left(34^{\circ} 16^{\prime 2} 29^{\prime \prime} \mathrm{S} 71^{\circ} 26^{\prime} 05^{\prime \prime} \mathrm{W}\right)$ arises from Piuquenes Mountain at an altitude of $4,460 \mathrm{~m}$, and is fed by the melting of a set of snowdrifts involving an area of $6,370 \mathrm{~km}^{2}$. The valley takes its name from the Cachapoal River that flows through Rapel valley along with its tributaries, the Claro and Cortaderal Rivers. All these watercourses flow into Rapel Lake ${ }^{19}$.

The Choapa River $\left(31^{\circ} 37^{\prime} 40^{\prime \prime} \mathrm{S} 71^{\circ} 33^{\prime} 30^{\prime \prime} \mathrm{O}\right)$ arises in the Andes range about $140 \mathrm{~km}$ from the sea and is formed by the confluence of the Totoral, Leiva and del Valle rivers, receiving downstream as a tributary to the Cuncumen River. On the north side it has two tributaries, the Chalinga River and the most important one, the Illapel River ${ }^{19}$

\subsection{Sampling collecting.}

Samples were taken in spring (November); summer (January), autumn (May) and winter (June). As shown in Figure 1, sediment samples from three selected basins were collected: Aconcagua, Cachapoal and Choapa basins at different points in the river. Selection was based on hydrologic criteria: ritron - very steep areas, therefore of high sediment transport, high-current speed, low temperatures and high oxygen concentrations; and potamon- higher temperatures, lower oxygen concentration and sandy substrates, which would produce sedimentation due to the decrease in slope ${ }^{20,21}$. Six sampling points were chosen in three areas: one station without human intervention (ritron: E1), two in the area of middle ritron to characterize the sediments (E2-E3) and a third in the sector potamon where increased sedimentation (E4-E5-E6). In the three basins site E2 could be influenced by mining activities, Coya River site E2 in the Cachapoal basin is influenced by the El Teniente mine; Blanco River site E2 in the Aconcagua basin influenced by the Cerro Blanco mine and Cumunen River site E2 in the Choapa basin is influenced by the Los Pelambres mine.

\subsection{Pretreatment of samples.}

We sampled sediments in each station in triplicate $(1 \mathrm{~kg}$ each, collected in polyethylene flasks) according to the protocol for sediments, ${ }^{22}$, which requires collecting samples with a plastic shovel from the top $10 \mathrm{~cm}$ of the superficial sediment zone. The three samples of each site were mixed to ensure that each site sample was representative. All samples were transported to laboratory and subsequently stored in a freezer at $-4{ }^{\circ} \mathrm{C}$ until analysis. Sediment samples were dried in polyethylene trays at temperatures below $40^{\circ} \mathrm{C}$ (dry air) and then sieved $<63$ microns grain size fraction which has a strong association with metals and stored in plastic jars.

\subsection{Characterization of Sediment.}

$\mathrm{pH}$, and electrical conductivity (EC) of the sediments were measured in situ using a portable multiparameter (VWR multi340i). In the laboratory, the Walkley-Black method was used to determine organic carbon and the Olsen method was used soluble phosphorous content ${ }^{23,24}$.

\subsection{Labile fraction determination.}

The soluble or labile fraction of sediment was determined in the four seasons: spring (November); summer (January), autumn (May) and winter (June). Samples of this fraction of the sediments were obtained by stirring $0.25 \mathrm{~g}$ samples with $40 \mathrm{~mL}$ acetic acid (Merck p.a.) $0.11 \mathrm{~mol} \mathrm{~L}^{-1}$ for $16 \mathrm{~h}$, and then centrifuged at $3500 \mathrm{rpm}$ for $30 \mathrm{~min}$ and filtered $(0.45 \mu \mathrm{m})$. Metals were analyzed by ICP-OES (Perkin Elmer Co, Optima-3300XI). USEPA SW 846 Method 6010 $\mathrm{B}^{25}$.

\subsection{Analytical method validation and quality control}

Standard solutions for trace elements were prepared from Titrisol $1000 \mathrm{mgL}^{-1}$ (Merck). To assure the accuracy of the data reported, recovery experiments were performed using standard reference material for sediments ((river sediment GBW 08301). The instrumental detection and quantification limist were estimated by analyzing ten blank solutions. The concentration ranges were based on the limit of detection (LOD) and the limit of quantification (LOQ) for each metal. The LOD and LQD were calculated for the original solid samples $\left(\mu \mathrm{gg}^{-1}\right)$ by taking into account the amount of sample digest and final volume obtained by dilution. Detection limits (LOD) of metals were: $\mathrm{As}=0.01 ; \mathrm{Al}=$ $0.27 ; \mathrm{B}=0.05 ; \mathrm{Cd}=0.06 ; \mathrm{Cu}=0.08 ; \mathrm{Cr}=0.10 ; \mathrm{Fe}=0.09 ; \mathrm{Mn}=0.18 ; \mathrm{Mo}=$ $0.10 ; \mathrm{Ni}=0.10 ; \mathrm{Pb}=0.01 ; \mathrm{Zn}=0.13 \mu \mathrm{gg}-1$. The experiment was performed in triplicate using the sample from each site, Analytical curves were obtained with a correlation coefficient $(\mathrm{R})$ equal or close to $1\left(\mathrm{R}^{2}>0.999\right)$. The calibration curves for all the studied elements were in the range of 0.01 to $1.0 \mathrm{mg} \mathrm{L}^{-1}$. The accuracy was measured in relation to coefficient of variation (CV), finding that for all the measurements performed in different days the $\mathrm{CV}$ was less than $5 \%$, The method showed good accuracy, with recovery values between $99 \pm 3$ and $104 \pm 1 \%$ in relation to the reference material (river sediment GBW 08301).

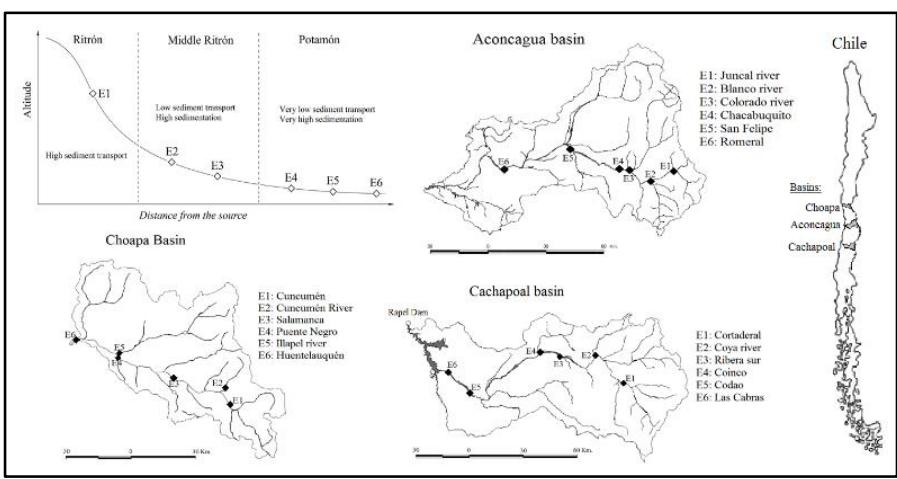

Figure 1. Sampling stations in the three basins ${ }^{26}$.

\section{RESULTS AND DISCUSSIONS}

\subsection{Characterization of Sediment}

The following figures (figures 2, 3, 4 and 5) show results of sediment characteristics in the three basins in the four seasons.
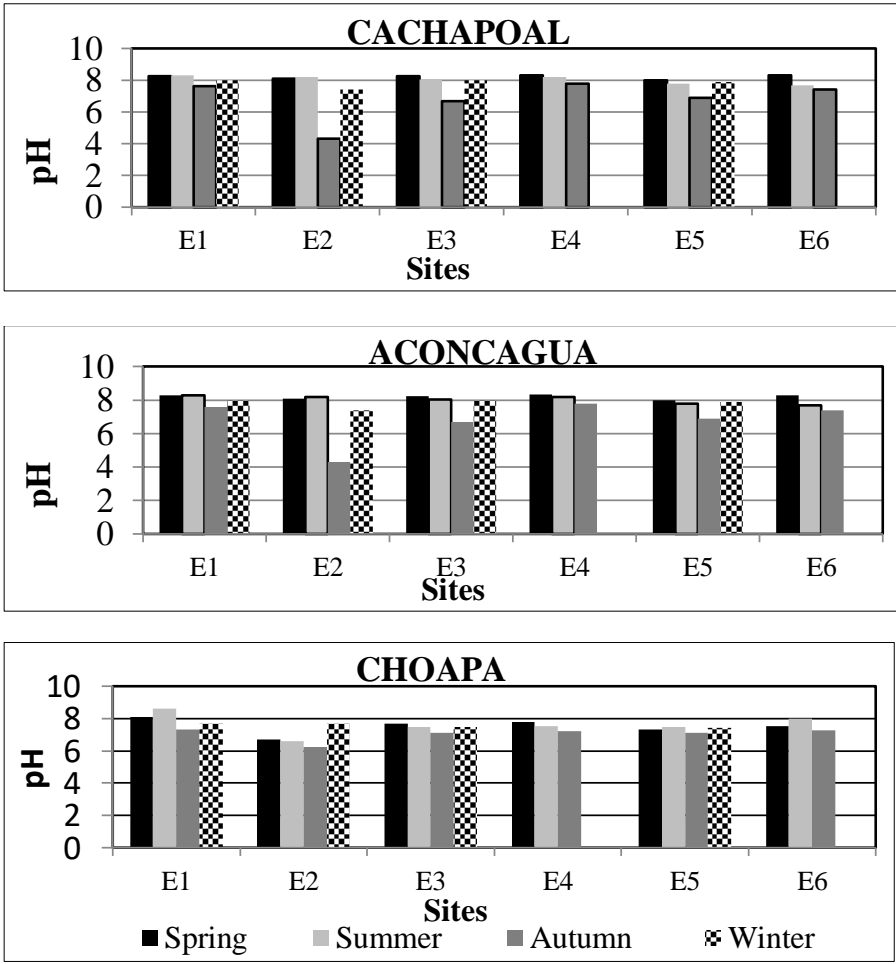

Figure 2. $\mathrm{pH}$ values for the three basins and four seasons, (each value is the mean of three replicates). Samples were not collected (NC), in winter, sites 4 and 6.

From the figure 2, it can be seen that the $\mathrm{pH}$ was slightly alkaline in all the basins, without showing great variation in the seasons and sites range 6.50 to 8.55 in the Cachapoal River; 4.30 to 8.33 in the Aconcagua River and 6.23 to 8.63 in the Choapa River. The only exception is an acid pH in the Aconcagua River in autumn (4.30), probably due to some mining spillage. A similar $\mathrm{pH}$ range has been observed in the sediment of the Tao-Che River (Taiwan) ${ }^{27}$ and in some other Chilean basins ${ }^{28}$. The $\mathrm{pH}$ is related to the availability of metals, 
which tend to be more available in acidic environments due to the absence of hydroxy-complex, which causes precipitation, and increases solubility and mobility ${ }^{29}$. Previous trace elements studies have indicated that levels of moderately basic $\mathrm{pH}$, i.e. between 6 and 8 , facilitate the adsorption of metals in the sediment ${ }^{30}$. Thus in this case a predominantly neutral-alkaline $\mathrm{pH}$ indicates that metals would be less available in the water and adsorbed in the sediment ${ }^{31}$.
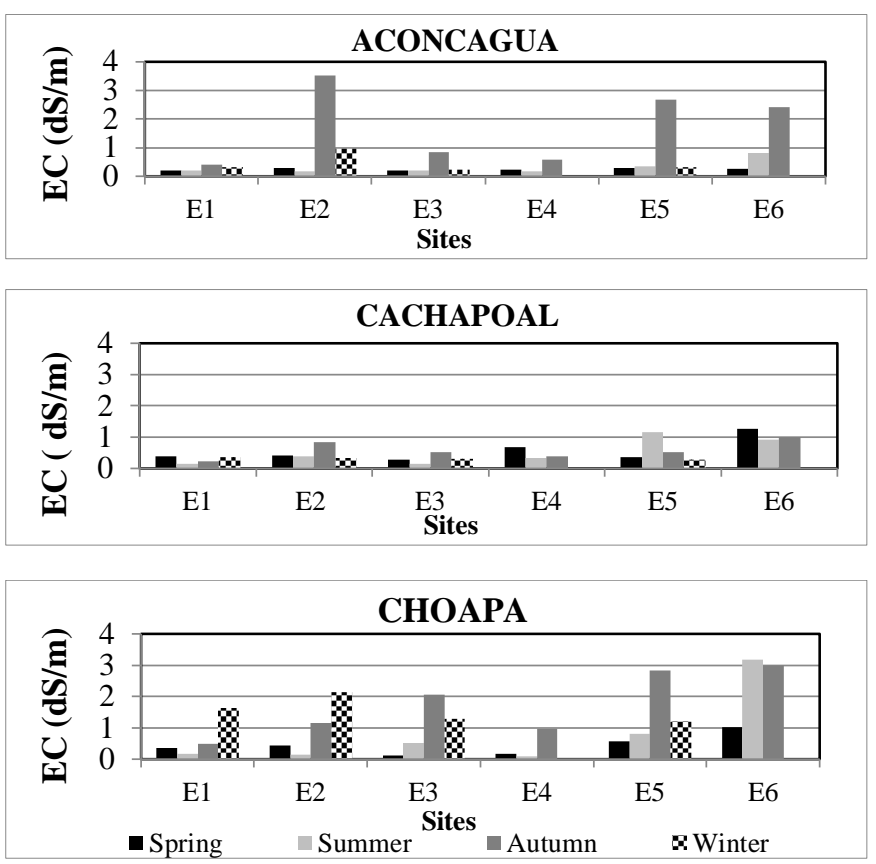

Figure 3. Electrical conductivity values $(\mathrm{CE}, \mathrm{dS} / \mathrm{m})$ for the three basins and four seasons, (each value is the mean of three replicates). Samples were not collected (NC), in winter, sites 4 and 6.

From figure 3, it can see that the EC showed dependence on the site, basin and station. The EC values in the Cachapoal River were lower than in the other basins. In Aconcagua, the E2 site (3.52 dS / m), E5 (2.69 dS / m) and E6 (2.41 $\mathrm{dS} / \mathrm{m}$ ) sites were high in autumn and in the Choapa E5 (3.15 dS / m; $2.60 \mathrm{dS} /$ $\mathrm{m}$ ) in summer and autumn respectively; values that would indicate slightly saline sediment.
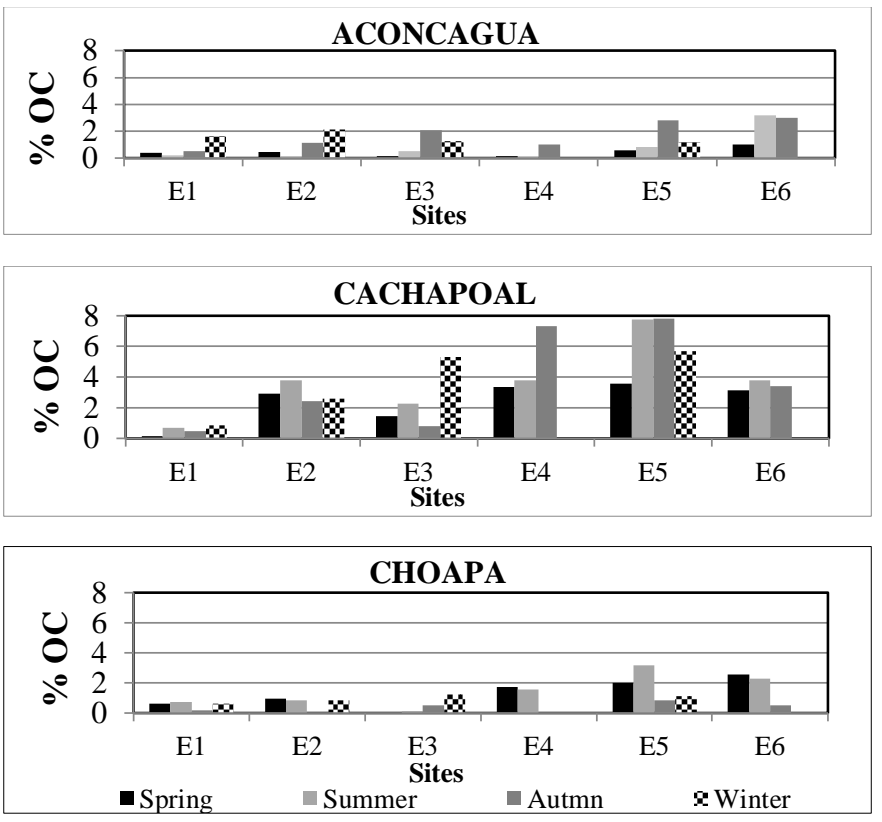

Figure 4. Organic carbon content (OC, \%), for the three basins and four seasons, (each value is the mean of three replicates), except for sites 4 and 6 in winter, where samples were not collected (NC).
From figure 4, it can see that the \% OC showed dependence on the site, basin and season. The hightest values of \%OC where found in the Aconcagua River site E3 (3.18\%) in summer and sites E3, E5 , E6 $(2.07 ; 2.84 ; 2.99 \%$ reapectively) in autumn. In Cachapoal River the highest values of \%OC where found in the sites E5 $(2,01 \% ; 3.19 \%)$ in spring and summer respectively and E6 $(2.56 \%$; $2.30 \%)$ in the some seasons. In Choapa River he highest values of \%OC in sites E5 (3.55-7.82) and E6 (3.80-3.16) in all seasons. For this Choapa River basins should be polluted by agricultural and waster water residues.
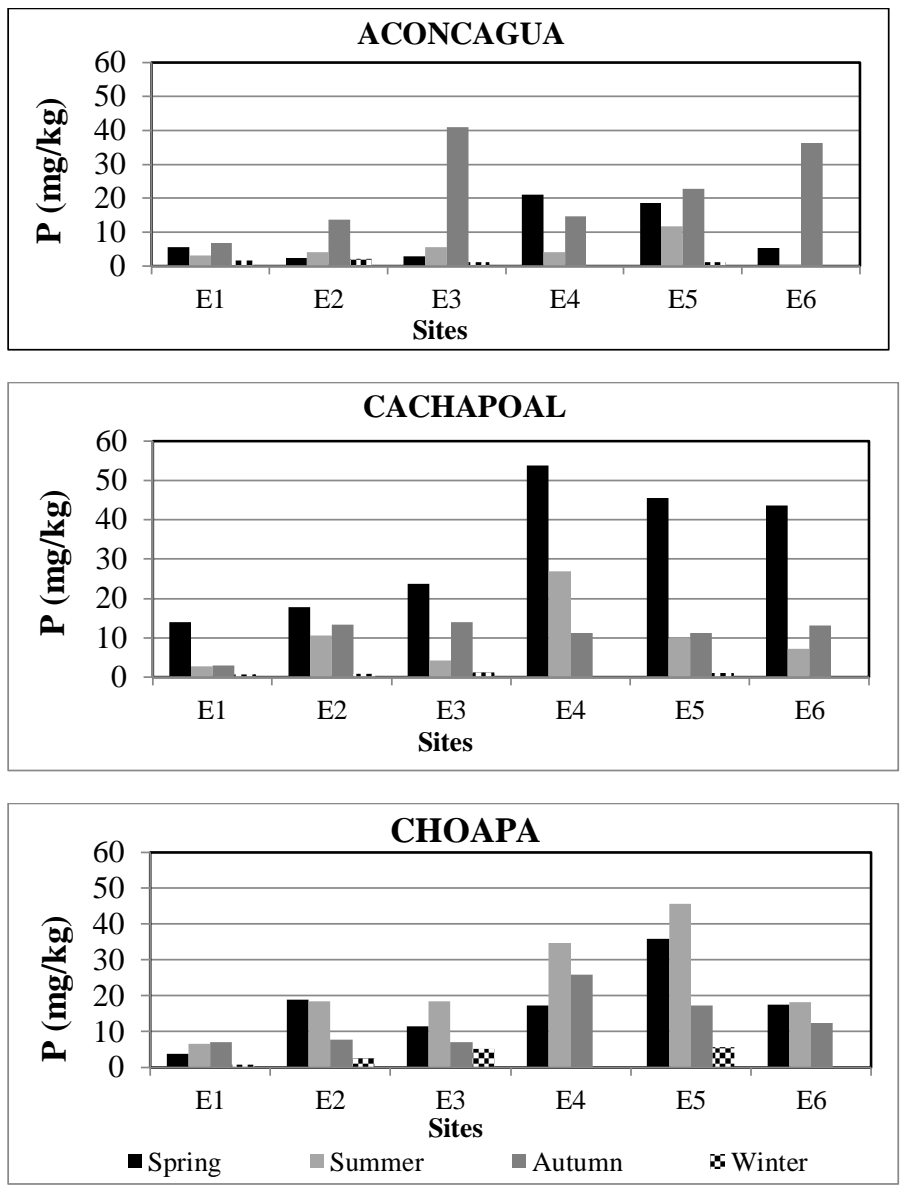

Figure 5. Water soluble phosphorous $\left(\mathrm{mgkg}^{-1}\right)$, for the three basins and four seasons, (each value is the mean of three replicates), except for sites 4 and 6 in winter, where samples were not collected (NC).

The available phosphorus content showed dependence on the site, basin and station. The sites E3 $\left(40.95 \mathrm{mgkg}^{-1}\right)$ and E6 (36.94 $\left.\mathrm{mgkg}^{-1}\right)$ in automn campaign in Aconcagua River and sites E4 (53.91 $\left.\mathrm{mgkg}^{-1}\right)$, E5 (45.47 $\left.\mathrm{mgkg}^{-1}\right)$ and E6 $\left(43.06 \mathrm{mgkg}^{-1}\right)$ spring campaign in Cachapoal River and the E5 site $(45.72 \mathrm{mgkg}$ 1) summer campaign in Choapa River, high values would correspond to anthropic intervention in these places, probably due to wastewater discharges and fertilizer use in agricultural sectors, similar values have been found in effluent of the $\mathrm{La}$ Paloma reservoir and effluent of the Recoleta reservoir ${ }^{28}$.

In general, the physical-chemical characteristics of sediment of three basins, electrical conductivity (EC), Organic Carbon (\% OC), water soluble phosphorous $(\mathrm{P})$, showed very different values along the river, which suggests that chemical species dissolved in the Chilean rivers are very different as a result of the basin heterogeneity in anthropogenic such as, waste water residues, mining activities, agricultural activities and natural environmental variability such as geological characteristics. High values of these parameters would be related to anthropic intervention, being these more significant in spring and summer due to the increase of the population in nearby places. Similar behavior has been found in other basins ${ }^{28}$.

\subsection{Determination of trace elements concentrations in the labile fraction}

The following tables (tables 1,2 and 3) show results of trace elements concentration, labile fraction in sediments in the three basins in the four seasons. 
Table 1. Trace elements concentration, labile fraction $\left(\mu \mathrm{gg}^{-1}\right)$ in the Aconcagua basin, four seasons. In winter samples were not collected from sites E3 and E6. Each value is the mean of three replicates.

SPRING

\begin{tabular}{|c|c|c|c|c|c|c|c|c|c|c|c|c|}
\hline Site & $\mathbf{C d}$ & $\mathbf{Z n}$ & $\mathbf{C r}$ & $\mathbf{C u}$ & $\mathbf{N i}$ & $\mathbf{P b}$ & $\mathbf{A l}$ & $\mathbf{M n}$ & $\mathbf{M o}$ & $\mathbf{B}$ & $\mathbf{F e}$ & $\mathbf{A s}$ \\
\hline E1 & $<$ LOD & 30.6 & 0.3 & 25.9 & 1.0 & 1.0 & 66.7 & 651.3 & $<$ LOD & $<$ LOD & 276.5 & $<$ LOD \\
\hline E2 & 0.4 & $\mathbf{1 2 8 . 5}$ & 0.2 & $\mathbf{3 4 8 6 . 4}$ & 9.0 & 2.0 & 659.9 & 636.0 & $<$ LOD & $<$ LOD & 140.8 & 36.1 \\
\hline E3 & $\mathbf{0 . 9}$ & 88.1 & 0.1 & $\mathbf{6 6 . 2}$ & 2.9 & 3.7 & 11.2 & 678.4 & $<$ LOD & $<$ LOD & 238.3 & $<$ LOD \\
\hline E4 & $\mathbf{1 . 0}$ & 81.9 & 0.1 & $\mathbf{4 9 7 . 9}$ & 4.0 & $<0.01$ & 56.9 & 526.9 & $<$ LOD & $<$ LOD & 30.9 & 87.0 \\
\hline E5 & $\mathbf{1 . 0}$ & 129.9 & 0.2 & $\mathbf{1 2 8 8 . 5}$ & 6.0 & $<0.01$ & 182.8 & 582.4 & $<$ LOD & $<$ LOD & 36.0 & 102.1 \\
\hline E6 & $\mathbf{0 . 7}$ & 89.2 & 0.2 & $\mathbf{1 2 5 9 . 7}$ & 2.3 & 2.7 & 299.4 & 621.9 & 0.1 & 2.0 & 36.3 & $<$ LOD \\
\hline
\end{tabular}

SUMMER

\begin{tabular}{|c|c|c|c|c|c|c|c|c|c|c|c|c|}
\hline Site & $\mathbf{C d}$ & $\mathbf{Z n}$ & $\mathbf{C r}$ & $\mathbf{C u}$ & $\mathbf{N i}$ & $\mathbf{P b}$ & $\mathbf{A l}$ & $\mathbf{M n}$ & $\mathbf{M o}$ & $\mathbf{B}$ & $\mathbf{F e}$ & $\mathbf{A s}$ \\
\hline E1 & $<$ LOD & 3.6 & 0.2 & 20.8 & 0.7 & 1.2 & 66.3 & 397.1 & $<$ LOD & 1.5 & 285.3 & $<$ LOD \\
\hline E2 & 0.1 & 33.6 & 0.2 & $\mathbf{8 4 2 . 0}$ & 2.1 & 2.2 & 2119.5 & 498.9 & $<$ LOD & 3.0 & 650.6 & 0.4 \\
\hline E3 & 0.6 & 25.2 & 0.4 & $\mathbf{7 4 . 9}$ & 1.9 & 1.6 & 1031.4 & 659.6 & $<$ LOD & 4.3 & 811.5 & $<$ LOD \\
\hline E4 & 0.1 & 21.5 & 0.2 & $\mathbf{5 6 2 . 0}$ & 1.5 & 2.4 & 204.2 & 494.4 & $<$ LOD & 2.1 & 462.6 & $<$ LOD \\
\hline E5 & 0.4 & 44.0 & 0.2 & $\mathbf{8 7 9 . 4}$ & 2.2 & 3.7 & 255.5 & 543.7 & $<$ LOD & 1.1 & 143.1 & 0.9 \\
\hline E6 & 0.5 & 31.5 & 0.3 & $\mathbf{8 7 6 . 3}$ & 1.5 & 3.4 & 136.3 & 737.1 & $<$ LOD & 2.0 & 139.5 & 3.3 \\
\hline
\end{tabular}

\section{AUTUMN}

\begin{tabular}{|c|c|c|c|c|c|c|c|c|c|c|c|c|}
\hline Site & $\mathbf{C d}$ & $\mathbf{Z n}$ & $\mathbf{C r}$ & $\mathbf{C u}$ & $\mathbf{N i}$ & $\mathbf{P b}$ & $\mathbf{A l}$ & $\mathbf{M n}$ & $\mathbf{M o}$ & $\mathbf{B}$ & $\mathbf{F e}$ & $\mathbf{A s}$ \\
\hline E1 & 0.2 & 10.2 & 0.1 & 11.0 & 0.1 & 0.5 & 76.4 & 451.9 & $<$ LOD & $<$ LOD & 48.7 & 8.9 \\
\hline E2 & $<$ LOD & 61.4 & 1.0 & $\mathbf{9 0 1 . 0}$ & 0.1 & 2.6 & 450.1 & 254.5 & $<$ LOD & $<$ LOD & 569.9 & 38.9 \\
\hline E3 & 0.3 & 11.7 & 0.1 & 4.0 & 0.6 & $<$ LOD & 101.0 & 399.3 & $<$ LOD & 0.1 & 1.2 & $<$ LOD \\
\hline E4 & 0.4 & 50.2 & 0.1 & $\mathbf{7 8 5 . 7}$ & 1.2 & 1.5 & 116.1 & 359.8 & $<$ LOD & 1.0 & 51.5 & 2.7 \\
\hline E5 & $\mathbf{0 . 8}$ & 92.6 & 0.2 & $\mathbf{7 8 2 . 1}$ & 2.3 & 2.5 & 308.5 & 201.6 & $<$ LOD & 6.1 & 1193.4 & 2.5 \\
\hline E6 & 0.2 & 6.1 & <LOD & 28.6 & 0.8 & $<$ LOD & 0.4 & 155.3 & $<$ LOD & 1.6 & 15.7 & 0.9 \\
\hline
\end{tabular}

\section{WINTER}

\begin{tabular}{|c|c|c|c|c|c|c|c|c|c|c|c|c|}
\hline Site & $\mathbf{C d}$ & $\mathbf{Z n}$ & $\mathbf{C r}$ & $\mathbf{C u}$ & $\mathbf{N i}$ & $\mathbf{P b}$ & $\mathbf{A l}$ & $\mathbf{M n}$ & $\mathbf{M o}$ & $\mathbf{B}$ & $\mathbf{F e}$ & $\mathbf{A s}$ \\
\hline E1 & $\mathbf{3 . 8}$ & 4.1 & <LOD & 17.2 & 0.6 & $<$ LOD & 76.1 & 534.2 & 0.2 & 1.8 & 126.4 & $<$ LOD \\
\hline E2 & $\mathbf{3 . 2}$ & 14.5 & LLOD & $\mathbf{3 5 3 . 2}$ & 0.5 & 1.4 & 89.8 & 490.9 & $<$ LOD & 3.0 & 486.9 & $<$ LOD \\
\hline E4 & $\mathbf{3 . 3}$ & 18.1 & LLOD & $\mathbf{2 0 6 . 4}$ & 0.8 & 0.7 & 79.0 & 277.9 & 0.4 & 1.3 & 10.2 & $<$ LOD \\
\hline E5 & 0.4 & 22.0 & <LOD & $\mathbf{2 0 7 . 1}$ & 1.3 & 1.2 & 131.0 & 326.5 & 0.2 & 1.3 & 72.9 & $<$ LOD \\
\hline
\end{tabular}

Table 2. Trace elements concentration, labile fraction $\left(\mu \mathrm{gg}^{-1}\right)$ in the Cachapoal basin, four seasons. In winter samples were not collected from sites E3 and E6. Each value is the mean of three replicates

SPRING

\begin{tabular}{|c|c|c|c|c|c|c|c|c|c|c|c|c|}
\hline Site & Cd & $\mathbf{Z n}$ & $\mathbf{C r}$ & $\mathbf{C u}$ & $\mathbf{N i}$ & $\mathbf{P b}$ & $\mathbf{A l}$ & $\mathbf{M n}$ & $\mathbf{M o}$ & $\mathbf{B}$ & $\mathbf{F e}$ & As \\
\hline E1 & 0.3 & 18.1 & 0.2 & 5.1 & 0.4 & $<\mathrm{LOD}$ & 10.1 & 108.7 & $<\mathrm{LOD}$ & 0.6 & 1.5 & 6.1 \\
\hline E2 & 0.2 & 100.9 & 0.3 & $\mathbf{3 1 6 8 . 7}$ & 3.2 & 8.7 & 71.7 & 202.0 & $<$ LOD & $<\mathrm{LOD}$ & 238.6 & 7.0 \\
\hline E3 & 0.3 & 68.8 & 0.2 & $\mathbf{6 6 5 . 0}$ & 2.2 & 4.5 & 114.3 & 345.8 & $<$ LOD & 1.0 & 353.6 & 4.8 \\
\hline E4 & 0.3 & 60.1 & 0.2 & $\mathbf{7 7 7 . 0}$ & 1.6 & 2.5 & 86.0 & 276.0 & $<$ LOD & 3.5 & 917.5 & 1.7 \\
\hline E5 & 0.1 & 36.1 & $<$ LOD & $\mathbf{8 8 . 8}$ & 1.3 & 0.6 & 47.4 & 626.6 & $<$ LOD & 0.6 & 64.2 & 1.3 \\
\hline E6 & 0.2 & 40.4 & 0.3 & $\mathbf{3 4 0 . 1}$ & 1.2 & 1.1 & 46.7 & 393.1 & $<$ LOD & 1.7 & 401.3 & $<$ LOD \\
\hline
\end{tabular}


SUMMER

\begin{tabular}{|c|c|c|c|c|c|c|c|c|c|c|c|c|}
\hline Site & Cd & Zn & $\mathrm{Cr}$ & $\mathbf{C u}$ & $\mathbf{N i}$ & $\mathbf{P b}$ & Al & Mn & Mo & B & $\mathrm{Fe}$ & As \\
\hline E1 & 0.2 & 5.3 & $<\mathrm{LOD}$ & 14.9 & $<$ LOD & 0.9 & 46.4 & 113.9 & $<\mathrm{LOD}$ & $<\mathrm{LOD}$ & 89.2 & 4.7 \\
\hline E2 & 0.4 & 115.6 & 0.1 & 3249.5 & 4.6 & 6.5 & 136.9 & 271.7 & $<\mathrm{LOD}$ & 0.9 & 54.4 & 0.1 \\
\hline E3 & 0.1 & 34.8 & 0.1 & 247.9 & 0.5 & 2.2 & 99.9 & 212.9 & $<\mathrm{LOD}$ & 0.9 & 186.9 & 1.6 \\
\hline $\mathrm{E} 4$ & 0.2 & 29.6 & 0.1 & 720.3 & $<\mathrm{LOD}$ & 1.4 & 95.3 & 284.2 & 1.0 & $<\mathrm{LOD}$ & 691.4 & 1.3 \\
\hline E5 & 0.4 & 20.0 & $<\mathrm{LOD}$ & 129.4 & 0.2 & 2.2 & 44.9 & 300.7 & 0.7 & 0.1 & 331.1 & 9.3 \\
\hline E6 & 0.4 & 21.1 & 0.1 & 178.6 & 0.1 & 1.6 & 44.4 & 260.2 & 0.6 & $<$ LOD & 261.8 & 15.9 \\
\hline
\end{tabular}

AUTUMN

\begin{tabular}{|c|c|c|c|c|c|c|c|c|c|c|c|c|}
\hline Sites & $\mathbf{C d}$ & $\mathbf{Z n}$ & $\mathbf{C r}$ & $\mathbf{C u}$ & $\mathbf{N i}$ & $\mathbf{P b}$ & $\mathbf{A l}$ & $\mathbf{M n}$ & $\mathbf{M o}$ & $\mathbf{B}$ & $\mathbf{F e}$ & $\mathbf{A s}$ \\
\hline E1 & 0.1 & 2.1 & 0.1 & 18.1 & 0.2 & 0.2 & 105.3 & 276.0 & $<$ LOD & 0.5 & 21.4 & $<$ LOD \\
\hline E2 & LLOD & 20.0 & 0.1 & $\mathbf{2 3 5 2 . 6}$ & 1.3 & 4.3 & 56.2 & 125.2 & $<$ LOD & 0.9 & 111.7 & 2.6 \\
\hline E3 & 0.1 & 27.7 & 0.1 & $\mathbf{2 3 9 . 7}$ & 0.8 & 2.4 & 84.6 & 244.3 & $<$ LOD & $<$ LOD & 178.0 & 0.4 \\
\hline E4 & 0.1 & 15.3 & 0.1 & $\mathbf{7 3 9 . 9}$ & 0.6 & 1.4 & 90.6 & 182.4 & $<$ LOD & 0.8 & 19.5 & 1.9 \\
\hline E5 & 0.1 & 8.4 & 0.1 & $\mathbf{1 2 8 . 6}$ & 0.7 & 0.3 & 71.0 & 218.1 & $<$ LOD & 0.9 & 9.5 & 0.1 \\
\hline E6 & 0.1 & 16.6 & 0.1 & $\mathbf{1 7 8 . 4}$ & 0.8 & 0.8 & 77.9 & 226.2 & $<$ LOD & 0.9 & 11.2 & 0.4 \\
\hline
\end{tabular}

WINTER

\begin{tabular}{|c|c|c|c|c|c|c|c|c|c|c|c|c|}
\hline Sites & $\mathbf{C d}$ & $\mathbf{Z n}$ & $\mathbf{C r}$ & $\mathbf{C u}$ & $\mathbf{N i}$ & $\mathbf{P b}$ & $\mathbf{A l}$ & $\mathbf{M n}$ & $\mathbf{M o}$ & $\mathbf{B}$ & $\mathbf{F e}$ & As \\
\hline E1 & $\mathbf{2 . 8}$ & 10.2 & $<$ LOD & $\mathbf{2 5 7 . 6}$ & 0.6 & 0.5 & 68.8 & 207.2 & 0.3 & 1.7 & 32.5 & $<\mathrm{LOD}$ \\
\hline E2 & $\mathbf{3 . 1}$ & 24.4 & $<$ LOD & $\mathbf{1 2 0 3 . 0}$ & 1.7 & 4.0 & 61.5 & 186.6 & $<$ LOD & 2.2 & 187.4 & $<\mathrm{LOD}$ \\
\hline E4 & $\mathbf{3 . 9}$ & 22.2 & $<$ LOD & $\mathbf{3 0 3 . 2}$ & 0.8 & 1.0 & 79.4 & 219.4 & $<$ LOD & 2.1 & 100.1 & $<\mathrm{LOD}$ \\
\hline E5 & $\mathbf{2 . 4}$ & 8.6 & $<$ LOD & $\mathbf{2 5 5 . 4}$ & 0,6 & 0.8 & 69.0 & 193.5 & $<\mathrm{LOD}$ & 1.7 & 40.5 & $<\mathrm{LOD}$ \\
\hline
\end{tabular}

Table 3. Trace elements concentration, labile fraction $\left(\mu \mathrm{gg}^{-1}\right)$ in the Choapa basin, four seasons. In winter samples were not collected from sites E3 and E6. Each value is the mean of three replicates

SPRING

\begin{tabular}{|c|c|c|c|c|c|c|c|c|c|c|c|c|}
\hline Sites & Cd & $\mathbf{Z n}$ & $\mathrm{Cr}$ & $\mathrm{Cu}$ & $\mathrm{Ni}$ & $\mathbf{P b}$ & Al & Mn & Mo & B & $\mathrm{Fe}$ & As \\
\hline E1 & 0.2 & 21.1 & 0.1 & 20.3 & 0.8 & 0.2 & 67.9 & 299.9 & $<\mathrm{LOD}$ & 1.8 & 6.3 & $<\mathrm{LOD}$ \\
\hline E2 & 2.4 & 270.8 & 0.2 & 2523.2 & 4.4 & 4.5 & 230.2 & 591.8 & 0.1 & 8.0 & 1047.4 & $<\mathrm{LOD}$ \\
\hline E3 & 0.2 & 20.9 & 0.1 & 16.9 & 0.8 & 0.3 & 69.4 & 323.6 & 0.1 & 2.3 & 40.5 & $<\mathrm{LOD}$ \\
\hline E4 & 0.2 & 18.8 & $<\mathrm{LOD}$ & 20.5 & 0.8 & $<\mathrm{LOD}$ & 34.0 & 275.8 & $<\mathrm{LOD}$ & 3.2 & 25.5 & $<\mathrm{LOD}$ \\
\hline E5 & 0.1 & 11.7 & $<\mathrm{LOD}$ & 26.5 & 1.0 & 0.5 & 24.5 & 347.4 & $<\mathrm{LOD}$ & 4.1 & 148.9 & $<\mathrm{LOD}$ \\
\hline E6 & 0.2 & 12.9 & $<\mathrm{LOD}$ & 15.8 & 0.5 & $<\mathrm{LOD}$ & 35.8 & 204.3 & $<\mathrm{LOD}$ & 4.2 & 81.3 & $<\mathrm{LOD}$ \\
\hline
\end{tabular}

SUMMER

\begin{tabular}{|c|c|c|c|c|c|c|c|c|c|c|c|c|}
\hline Sites & Cd & $\mathbf{Z n}$ & $\mathrm{Cr}$ & $\mathrm{Cu}$ & $\mathrm{Ni}$ & $\mathbf{P b}$ & Al & Mn & Mo & B & $\mathrm{Fe}$ & As \\
\hline E1 & 0.20 & 18.9 & 0.1 & 13.1 & 1.0 & 0.2 & 80.0 & 313.2 & $<\mathrm{LOD}$ & 1.1 & 2.0 & $<\mathrm{LOD}$ \\
\hline E2 & 2.32 & 258.5 & 0.2 & 2485.0 & 3.8 & 4.5 & 267.3 & 539.4 & $<\mathrm{LOD}$ & 8.0 & 1230.3 & $<\mathrm{LOD}$ \\
\hline E3 & 0.32 & 24.7 & 0.1 & 18.9 & 0.9 & 0.5 & 78.3 & 213.7 & $<\mathrm{LOD}$ & 3.8 & 277.4 & $<\mathrm{LOD}$ \\
\hline E4 & 0.08 & 9.6 & $<\mathrm{LOD}$ & 5.6 & 0.2 & 0.4 & 13.6 & 172.3 & $<\mathrm{LOD}$ & 4.5 & 18.9 & $<\mathrm{LOD}$ \\
\hline E5 & $<\mathrm{LOD}$ & 4.2 & $<\mathrm{LOD}$ & 3.1 & 0.7 & $<$ LOD & 1.0 & 139,97 & $<\mathrm{LOD}$ & 5.3 & 1.6 & $<\mathrm{LOD}$ \\
\hline E6 & 0.20 & 13.5 & $<\mathrm{LOD}$ & 14.7 & 0.7 & $<$ LOD & 26.6 & 125.8 & $<\mathrm{LOD}$ & 4.6 & 133.6 & $<\mathrm{LOD}$ \\
\hline
\end{tabular}


AUTUMN

\begin{tabular}{|c|c|c|c|c|c|c|c|c|c|c|c|c|}
\hline Sites & Cd & $\mathbf{Z n}$ & $\mathrm{Cr}$ & $\mathrm{Cu}$ & $\mathbf{N i}$ & $\mathbf{P b}$ & Al & Mn & Mo & B & $\mathrm{Fe}$ & As \\
\hline E1 & 0.4 & 50.1 & 0.2 & 51.7 & 1.6 & 0.4 & 181.9 & 450.7 & $<\mathrm{LOD}$ & 1.9 & 29.1 & $<\mathrm{LOD}$ \\
\hline E2 & 1.6 & 182.4 & 0.2 & 1733.1 & 2.8 & 4.3 & 158.9 & 658.9 & $<\mathrm{LOD}$ & 5.4 & 631.0 & $<\mathrm{LOD}$ \\
\hline E3 & 0.2 & 25.7 & $<\mathrm{LOD}$ & 19.2 & 0.8 & 0.6 & 57.5 & 184.9 & $<\mathrm{LOD}$ & 3.4 & 327.0 & $<\mathrm{LOD}$ \\
\hline E4 & $<\mathrm{LOD}$ & 5.1 & $<\mathrm{LOD}$ & 1.0 & 0.6 & 0.2 & $<\mathrm{LOD}$ & 232.5 & $<\mathrm{LOD}$ & 6.1 & 0.7 & $<\mathrm{LOD}$ \\
\hline E5 & $<\mathrm{LOD}$ & 8.1 & $<\mathrm{LOD}$ & 2.6 & 0.9 & $<\mathrm{LOD}$ & 2.0 & 212.8 & $<\mathrm{LOD}$ & 3.8 & 1.6 & $<\mathrm{LOD}$ \\
\hline E6 & 0.2 & 14.7 & $<\mathrm{LOD}$ & 15.3 & 0.5 & $<\mathrm{LOD}$ & 32.4 & 167.2 & $<\mathrm{LOD}$ & 2.9 & 110.8 & $<\mathrm{LOD}$ \\
\hline
\end{tabular}

WINTER

\begin{tabular}{|c|c|c|c|c|c|c|c|c|c|c|c|c|}
\hline Sites & $\mathbf{C d}$ & $\mathbf{Z n}$ & $\mathbf{C r}$ & $\mathbf{C u}$ & $\mathbf{N i}$ & $\mathbf{P b}$ & $\mathbf{A l}$ & $\mathbf{M n}$ & $\mathbf{M o}$ & $\mathbf{B}$ & $\mathbf{F e}$ & $\mathbf{A s}$ \\
\hline E1 & $\mathbf{3 . 4}$ & 13.8 & <LOD & 20.0 & 0.8 & 0.4 & 53.0 & 360.0 & $<$ LOD & 1.9 & 137.3 & $<\mathrm{LOD}$ \\
\hline E2 & 0.6 & 52.1 & LLOD & $\mathbf{3 2 2 . 2}$ & 1.0 & 1.0 & 48.1 & 401.8 & 0.4 & 1.4 & 6.6 & $<\mathrm{LOD}$ \\
\hline E4 & $\mathbf{2 . 9}$ & 2.8 & <LOD & 2.9 & 3.8 & $<\mathrm{LOD}$ & 1.7 & 227.9 & $<\mathrm{LOD}$ & 5.1 & 1.3 & $<\mathrm{LOD}$ \\
\hline E5 & $\mathbf{3 . 4}$ & 6.1 & <LOD & 9.7 & 0.6 & $<\mathrm{LOD}$ & 14.2 & 277.6 & $<\mathrm{LOD}$ & 5.4 & 12.4 & $<\mathrm{LOD}$ \\
\hline
\end{tabular}

The metal concentrations of the labile fraction of trace elements in sediment of the three basins were recorded for $\mathrm{Al}, \mathrm{As}, \mathrm{B}, \mathrm{Cd}, \mathrm{Cr}, \mathrm{Cu}, \mathrm{Fe}, \mathrm{Mn}, \mathrm{Mo}, \mathrm{Ni}, \mathrm{Pb}$ and $\mathrm{Zn}$. In table 1, 2 and 3, was observed a similar behavior in the three basins, that is, lower concentrations of labile fraction for trace elements, in the autumn and winter seasons, especially in winter, probably due to dilution due to rains. In the three basins B, Cd, and Mo were not detected in most of the seasons and sites. Note the high concentration of As found in the Aconcagua basin in spring in E2 (36.1 $\left.\mu \mathrm{gg}^{-1}\right)$, E3 $\left(87.0 \mu \mathrm{gg}^{-1}\right)$ and E5 $\left(102.1 \mu \mathrm{gg}^{-1}\right)$ and in site E2 $\left(38.6 \mu \mathrm{gg}^{-1)}\right.$ in autumn; this could also be related to the mining activity near the site E2 and the influence of the proximity to the mining companies to the other sites; in the others sites and basins As concentration was below detection limit, $\mathrm{Cr}$ and $\mathrm{Ni}$ were found in most of seasons and sites in the three basins, but in a lower concentration. Ni ranged between $9.0 \mu \mathrm{gg}^{-1}$ to below detection limit in the three basins; Cr ranged between $1.0 \mu \mathrm{gg}^{-1}$ to below detection limit in the three basins The highest concentrations were found for $\mathrm{Al}, \mathrm{Cu}, \mathrm{Mn}, \mathrm{Fe}$ and $\mathrm{Zn}$, labile fraction, for the most of seasons and sites.

International standards related to trace elements concentration values are oriented towards the toxicity of these elements, especially considering the total fraction. Concentration values of trace elements in fluvial sediments in the soluble fraction are scarce, Canadian Sediment Guidelines for the Protection of Aquatic Life has set maximum limits for some elements such as : $\mathrm{Cd}=0.60$; $\mathrm{Zn}=123.00 ; \mathrm{Cr}=37.30 ; \mathrm{Cu}=35.70 ; \mathrm{Ni}=100.00 ; \mathrm{Pb}=35.00^{32}$; elements that exceed these concentration limits determined, in the three basins and in all places are marked in bold in tables 1,2 and 3 .

Concentrations of labile fraction of $\mathrm{Cu}, \mathrm{Cd}, \mathrm{Pb}$ and $\mathrm{Zn}$ have been determined in Mapocho River (Santiago, Chile) in spring, summer, autumn and winter in six sites ${ }^{33}$. In the Mapocho river concentration of $\mathrm{Cu}$ is between 1771 to $32 \mu \mathrm{gg}^{-1}$ while the concentration of $\mathrm{Cu}$ in our work is between 3167.8 to $2.6, \mu \mathrm{gg}^{-1}$ The concentration of $\mathrm{Zn}$ in Mapocho river is between 555 to $106 \mu \mathrm{gg}^{-1}$, while the $\mathrm{Zn}$ concentration in the three is basins between 270.8 to $2.8 \mu \mathrm{gg}^{-1}$. Pb concentration in Mapocho river is between 0.2 to $1.0 \mu \mathrm{gg}^{-1}$ while in the three basins the concentration of $\mathrm{Pb}$ is between 8.7 to $<\mathrm{LOD} \mu \mathrm{gg}^{-1}$; the $\mathrm{Cd}$ concentration in Mapocho river is between 0.5 to $0.2 \mu \mathrm{gg}^{-1}$ while the $\mathrm{Cd}$ concentration in the three basins is between 3.9 to $<\mathrm{LOD} \mu \mathrm{gg}^{-1}$. In general, it can be seen that the values for the elements analyzed at the Mapocho River sites are slightly lower than the concentrations determined in the three basins, especially when they are compared to the E2 site.

3.7 Al, $\mathrm{Cu}, \mathrm{Fe}, \mathrm{Mn}$ and $\mathrm{Zn}$ concentration of labile fraction distribution in the three basins

The spatial and seasonal distribution of $\mathrm{Al}, \mathrm{Cu}, \mathrm{Fe}, \mathrm{Mn}$ and $\mathrm{Zn}$ concentration in labile fraction of the three basins are shown in next figures
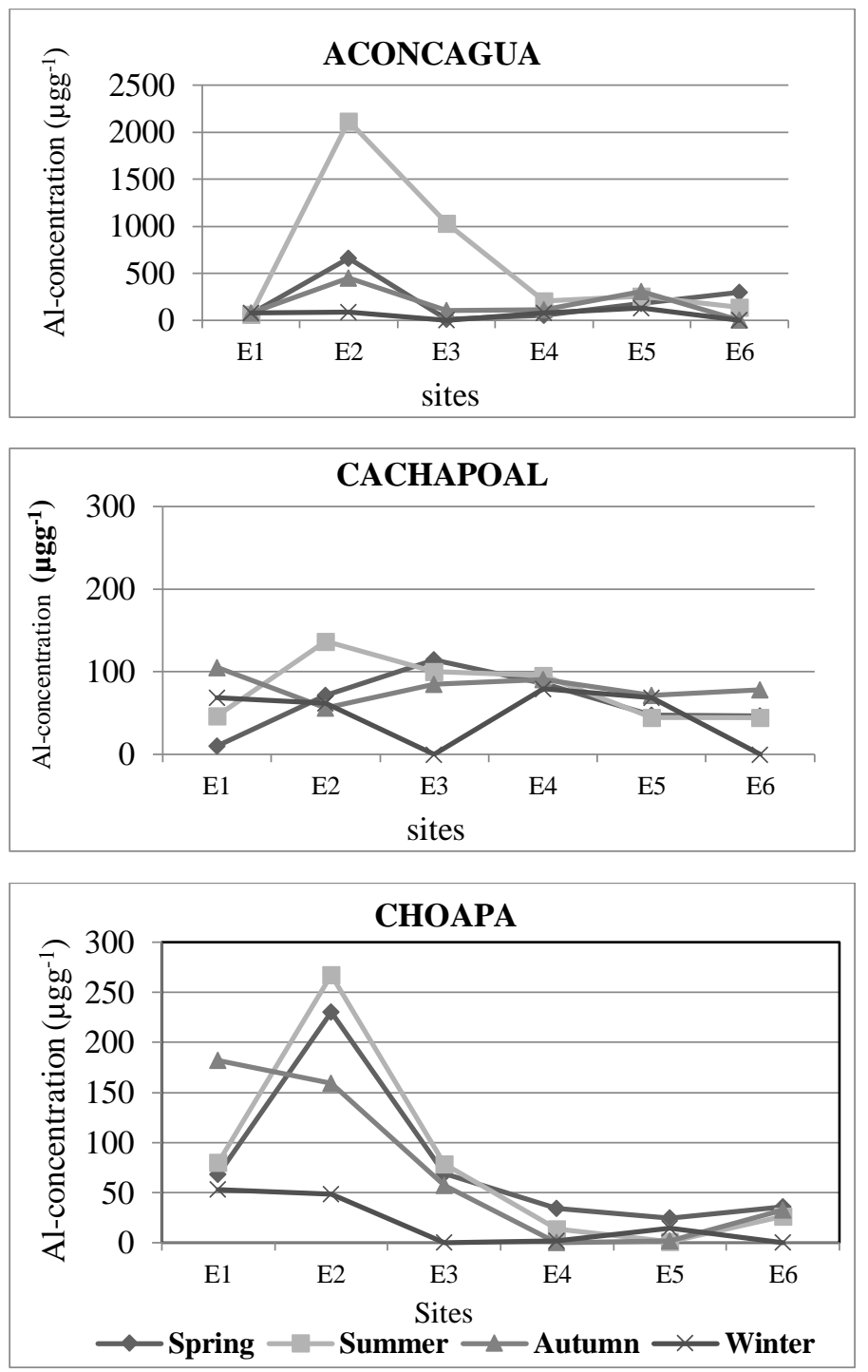

Figure 6 illustrates graphically the variation of $\mathrm{Al}$ concentration $\left(\mu \mathrm{gg}^{-1}\right)$, the labile fraction along the rivers and between seasons. 
From the figure 6 , it can be observed that the Al concentrations show spatial and seasonal variation in the three basins, this variation is observed much more in the Aconcagua and Choapa basins especially in site E2. By other hand the concentrations of $\mathrm{Al}$ found in Aconcagua basin (2119.5 $\mu \mathrm{gg}^{-1}, \mathrm{E} 2$, summer), was highest than in the other basins. In Cachapoal River, Al concentration it is no influenced by mining nearby.
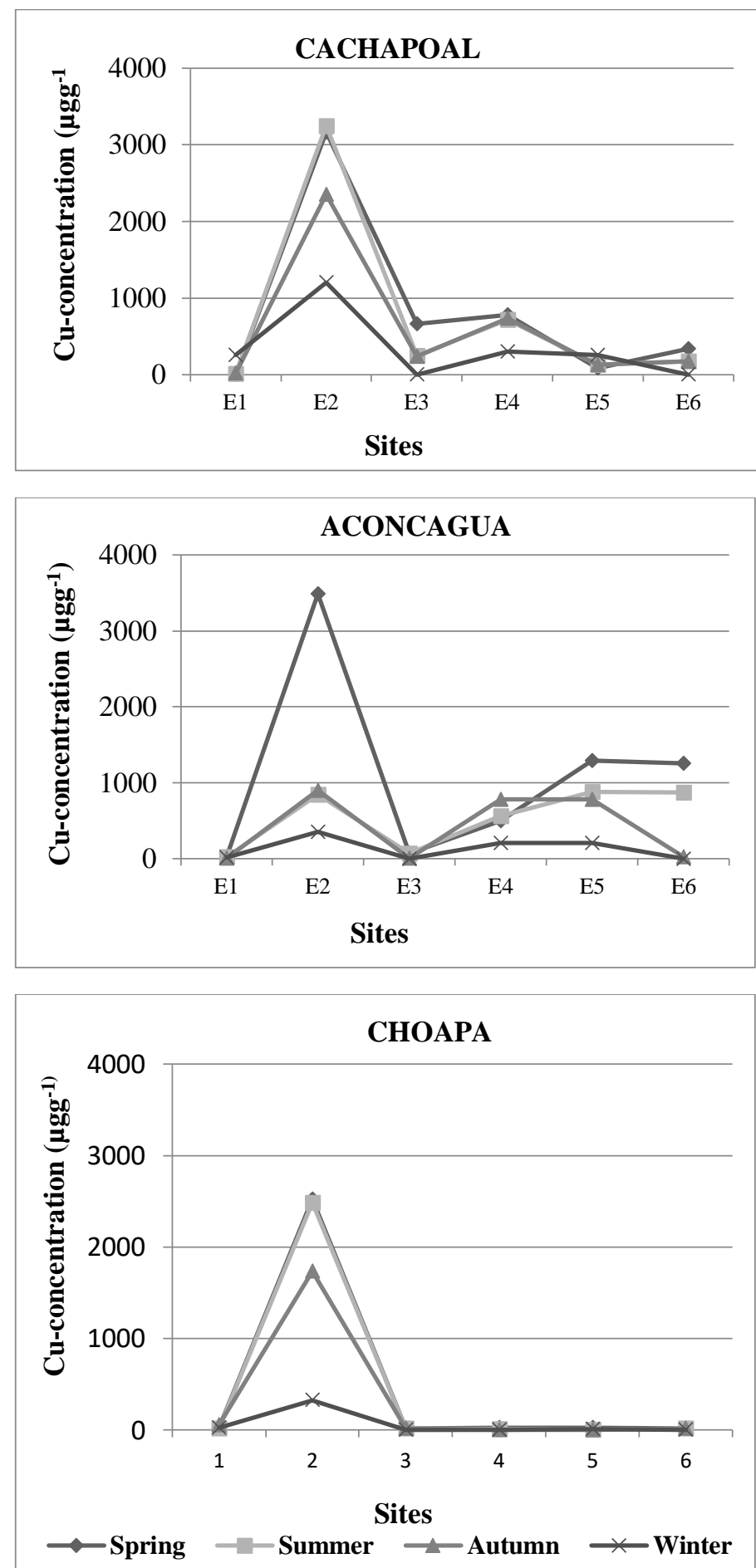

Figure 7 illustrates graphically the variation of $\mathrm{Cu}$ concentration $\left(\mu \mathrm{gg}^{-1}\right)$, the labile fraction along the rivers and between seasons in the three basins.

From the figure 7, it can be observed that the $\mathrm{Cu}$ concentrations show spatial and seasonal variation in the three basins. Additionally there was no significant mobility of the $\mathrm{Cu}$ concentration along the Choapa River, since the concentration decreased towards the E6 site; this is important because the nearby middle Ritron and Potamon sites are more populated.
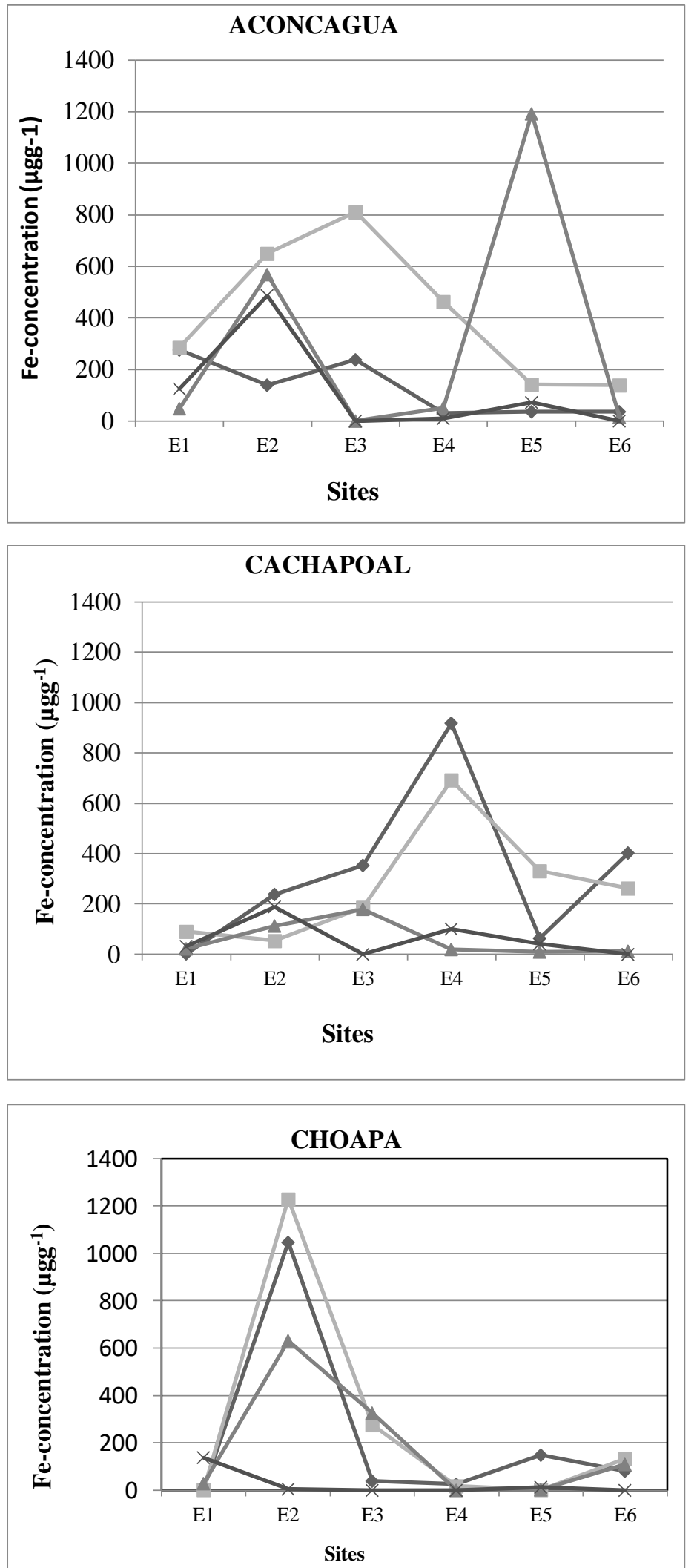

$\multimap$ Spring $\longleftarrow$ Summer $\leftarrow$ Autumn $\longleftarrow$ Winter

Figure 8 illustrates graphically the variation of Fe concentration $\left(\mu \mathrm{gg}^{-1}\right)$, the labile fraction along the rivers and between seasons in the three basins.

From the figure 8, it can be observed that the Fe concentrations show spatial and seasonal variation in the three basins, this variation is observed much more in the Choapa basin, site E2. 

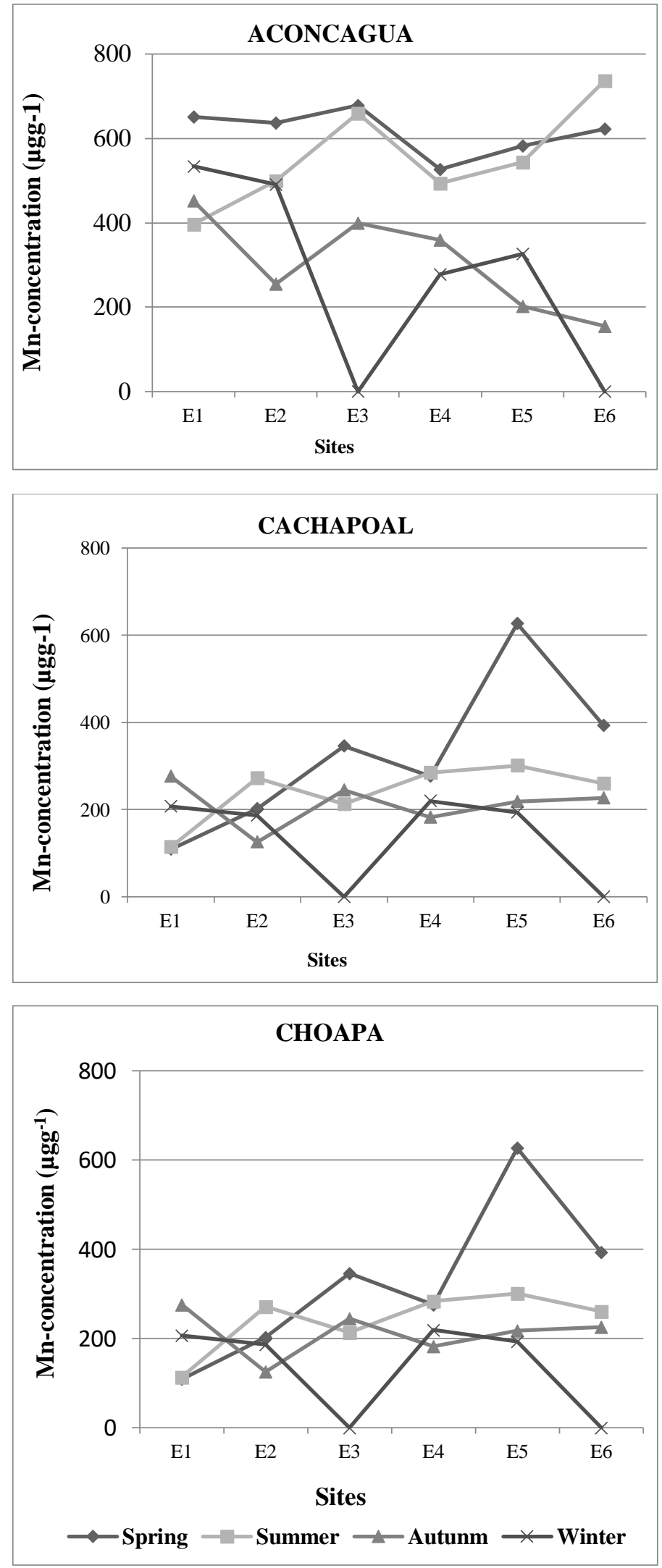

Figure 9 illustrates graphically the variation of Mn concentration $\left(\mu \mathrm{gg}^{-1}\right)$, the labile fraction along the rivers and between seasons in the three basins.

From the figure 9, it can be observed that the Mn concentrations show spatial and seasonal variation in the three basins. The distribution of this elements is randomize along the river. For this elements there no clear the influence for mining activities in the site E2
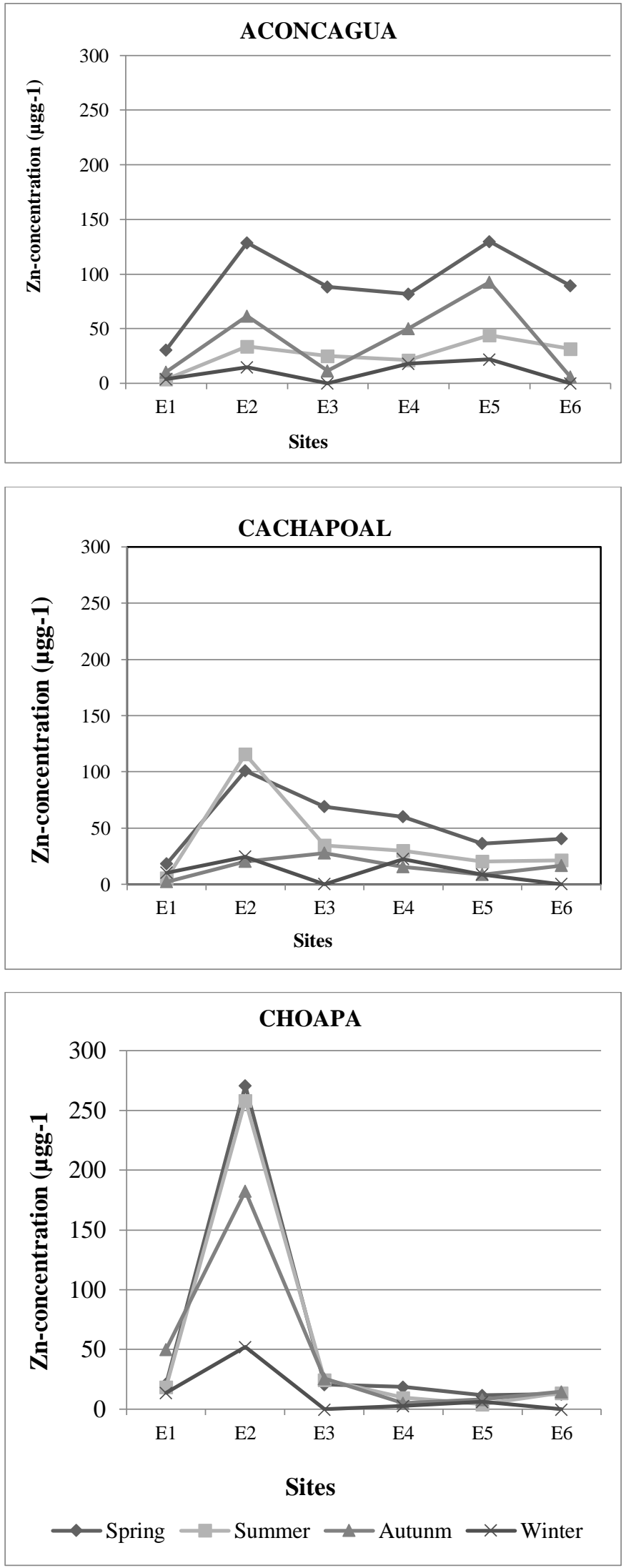

Figure 10 illustrates graphically the variation of $\mathrm{Zn}$ concentration $\left(\mu \mathrm{gg}^{-1}\right)$, the labile fraction along the rivers and between seasons in the three basins.

From the figure 10, it can be observed that the $\mathrm{Zn}$ concentrations show a little spatial variation in the three basins, seasonal variation is observed much more in the three basins, especially in Choapa river. 
The highest $\mathrm{Cu}, \mathrm{Fe}, \mathrm{Mn}$ and $\mathrm{Zn}$ concentrations in the sediment in site $\mathrm{E} 2$ for the three basins could attribute to the nearby mining activities; Aconcagua: El Teniente mine, Cachapoal: Cerro Blanco mine and Choapa: Los Pelambres mine. The effect of the proximity to the mines in front of the sediments of the three basins would indicate greater importance in spring and summer probably after temperature effect and population increase; the latter influencing a lower purification of the river due to greater use of the water and evaporation.

\section{CONCLUSIONS}

The physical chemistry characterization of sediments in the three basins: $\mathrm{pH}$, $\mathrm{EC}, \% \mathrm{OC}$ and water soluble phosphorous show differences between basins and between sites, this could be attribute at rivers characteristics related with anthropic intervention.

The metal concentrations of the labile fraction of trace elements in sediment of the three basins were recorded for $\mathrm{Al}, \mathrm{As}, \mathrm{B}, \mathrm{Cd}, \mathrm{Cr}, \mathrm{Cu}, \mathrm{Fe}, \mathrm{Mn}, \mathrm{Mo}, \mathrm{Ni}, \mathrm{Pb}$ and $\mathrm{Zn}$. Was observed a similar behavior in the three basins, that is, lower concentrations of labile fraction for trace elements, in the autumn and winter seasons.

The highest concentrations were found for $\mathrm{Al}, \mathrm{Cu}, \mathrm{Mn}, \mathrm{Fe}$ and $\mathrm{Zn}$, labile fraction, for the most of seasons and sites. The other elements were in lower concentration or bellow detection limit. Exception was observed for As in Aconcagua River in spring and autumn.

$\mathrm{Cu}$ in the most of sites and $\mathrm{Cd}$ and $\mathrm{Zn}$ in some sites were the elements that exceeded the maximum limits established from of Canadian Sediment Guidelines for the Protection of Aquatic Life.

The present study on concentration of trace elements in the labile fraction of sediment from three Chilean basins confirmed that there are significant relationships between seasons and between sites.

The high $\mathrm{Cu}$ concentrations found on site E2 confirm the effect of the proximity of mining activities; El Teniente mine in Cachapoal basin; Cerro Blanco mine in Aconcagua basin and Los Pelambres mine in Choapa basin. This effect was observed for $\mathrm{Al}$ in Aconcagua and Choapa river; Fe and $\mathrm{Zn}$ in Choapa river.

\section{ACKNOWLEDGMENTS}

This work has been financially by Dirección General de Aguas (DGA)-Código 300 65693-0 Chile. Centro Nacional del Medio Ambiente (CENMA) y Departamento de Química. Facultad de Ciencias. Universidad de Chile.

\section{CONFLICT OF INTEREST}

The authors declare that they have no conflict of interest.

\section{REFERENCES}

1. X. L. Gao. A. C. T. Chen,.ं Water Res 46, 1901, (2012).

2. R. K. Klake, V. K. Nartey, L. K. Doamekpor, K. A. Edor, J. Environ Prot. 3,1070, (2013).

3. M. Karvelas, K. Athanasion, C. Samara, Chemosphere 53, 120, (2003).

4. G. R. Mataba, V. Verhaert, R. Blust, L. Bervoest, Sci Tot Environ. 547, 48, (2016).

5. S. K. Gupta, M. Chabukdhara, J. Singh, F. Bux, Ecol. Risk Assess 21, 227, (2015).

6. M. D. Subida, A. Berihuete, P. Drake, J. Blasco, Sci. Total Environ 450-451, 280, (2013)..

7. Borja, H. Heinrich, Mar Pollut. Bull 50, 486, (2005).

8. K. Sebakira, H. Oryem Origa, T. A. Basamba, G. Mutumba, E. Kakudidid, In J Environ Sci Technol 7, 435, (2010).

9. X. Yuan, L. Zhang, J. Li, C. Wang, J. Ji, Catena 119, 52, (2014).

10. S. Peng, W. Wang, X. Li, Y. Yen, Chemosphere 57, 839, (2004).

11. A. Tessier, P. G. Cambell, M. Bisson, Anal. Chem. 51, 844, (1979).

12. S. V. Copaja, M. X. Molina, R.M. Tessada, J. Chil. Chem. Soc., 59: 2353, (2014).

13. J. Y. Kim, B. T. Lee, K. H. Shin, K. W. Kim, K. G. An, Y.S. Park, Y. Kim, Y. H. Kwon, Environ Monit. Assess 129, 79, (2007)

14. C. H. Qu, C. Z. Chen, J. R. Yang, L. Z. Wang, Y. L. Lu, Estuaries 16, 475, (1993).
15. R. Oyarzun, S. Guevara, J. Oyarzun, H. Lillo. P. Higueras, Geochem. Health 28, 431, (2006).

16. R. Oyarzun. J. Oyarzun. J. Lilo. H. Maturana. P. Higueras, Environ geol. 52, 283, (2007).

17. T. Vila. R.H. Sillitoe, Econ. Geil 86, 1238, (1991).

18. T. Ditmar. Total environ. 325, 193, (2004).

19. DGA (Dirección General de Aguas). Caracterización de Sedimentos Fluviales y su Relación con la Calidad del agua, pp 1-80, (2008).

20. F.R. Hauer, G.A. Lamberti, Methods in Stream Ecology, Second Ed., (Academic Press, USA, 1996).

21. R.L. Welcomme, Documentos Técnicos de Pesca N²02, FAO, 1-62 (1980).

22. S. I. Simpson, G. E. Batley, A. A. S. Charlston, J. L. Dtauber, C. K. King, J. C. Chapman, R. V. Hyne, S. A. Gale A. C. Roach, W. A. Maher, J. J. Sharyan, Handbook for Sediment Quality Assessment, (CSIRO Bangor, NSW), 2005; pp 9-19.

23. P. L. Blackemore, B. K. Searle. B. K. Daly, (1987) In Methods for Chemical Analysis of Soils, N. Z. Soil Bureau Scientific Report 80, p 18.

24. M. A. Sadzawka, A. Carrasco, R. Grez, M. Mora, H. Flores, A. Newman, Instituto de Investigaciones Agropecuarias (INIA). Serie Actas INIA N0 34 (2006).

25. U.S. EPA. 2014. "Method 6010D (SW-846): Inductively Coupled PlasmaAtomic Emission Spectrometry," Revision 4. Washington, DC.

26. S. V. Copaja, G. Díaz, R.Toro, R. M. Tessada, P. Miranda, J. R. Morales, J. Chil. Chem. Soc., 57, 1199, (2012)

27. J-G. Lin, S-Y. Chen, Environ Int 24, 345, (1998).

28. S. V. Copaja, V. R. Nuñez, G. S. Muñoz, G. L. González, I. Vila, D. Véliz, J Chil Chem Soc. 60, 2642, (2016).

29. F. Burriel, F. Marti, S. Lucena-Conde, J. Arribas-Jimeno, Hernández Méndez (2003) Química Analítica Cualitativa (Décimo Sexta Edición) (Editorial PARANINFO) Madrid, España. Chapter XIX y XX.

30. C.A. B. Garcia, M. S. Barreto, E. A. Passos, J. Patrocínio, H. Alves, J. Braz. Chem. Soc. 20. 1334, (2009).

31. Yi Wai. Chiang, K. Ghyselbrecht, R. M. Santos, J. A. Martens, R. Swennen, V. Cappuyns, B. Meesschaert, Chemical Engineering Journal 405, 200, (2012).

32. Protocol for the Derivation of Canadian Sediment Quality Guidelines for the Protection of Aquatic Life. Canadian Council of Ministers of the Environment 1995 CCME EPC-98E.

33. R. Segura, V. Arancibia, M. C. Zúñiga, P. Pastén. Journal of Geochemical Exploration, 91, 71. (2006). 